\title{
Electroconvulsive Therapy Before or After Initiation of Clozapine in Schizophrenia - A Retrospective Comparison for Seizure Parameters, Treatment Response and Duration of Hospitalization
}

\author{
Eren Yıldızhan ${ }^{1}$ (D) , Nesrin Buket Tomruk ${ }^{1}$ (D) , Özge Atay Canbek² (iD
}

'Bakırköy Research and Training Hospital for Psychiatry, Neurology and Neurosurgery, Department of Psychiatry, 14.Psikiyatri, Istanbul, Turkey

${ }^{2}$ Bakırköy Research and Training Hospital for Psychiatry, Neurology and Neurosurgery, Department of Psychiatry, ECT Research and Practice Center, Istanbul, Turkey

Eren YILDIZHAN

Nesrin Buket TOMRUK

Özge ATAY CANBEK

\section{Correspondence: Eren Yildızhan}

1Bakırköy Research and Training Hospital for Psychiatry, Neurology and Neurosurgery, Department of Psychiatry, 14.Psikiyatri, Istanbul, Turkey

Phone: +902124091515

E-mail: erenyildizhan@hotmail.com

\begin{abstract}
Purpose: Determining whether adjunctive electroconvulsive therapy (ECT) with clozapine leads to better treatment response and decreased length of stay for patients with schizophrenia.

Methods: Medical records of patients with schizophrenia who were treated with ECT-clozapine combination in our women's mental health inpatient clinic in a period of 5 years (between 01.02.2014 and 01.02.2019) were investigated retrospectively. Clinical Global Impression of Improvement (CGI-I) scale was used for assessing treatment response.

Results: of the 191 cases treated with ECT, there were 8 cases of schizophrenia who were treated with ECT and concomitant clozapine (C-ECT) and 14 cases who were treated with ECT before the initiation of clozapine (ECT-B). Number of ECT sessions and duration of seizures were not significantly different for both groups $(p>0.05)$. There was good and mild response (CGI-I score of 2 and 3 ) in $75 \%$ of the patients ( $n=6)$ for C-ECT and $85.7 \%$ of the patients ( $n=12)$ for ECT-B. Mean CGI-I scores between the two groups were not significantly different $(p>0.05)$. Duration of hospitalization for the C-ECT group ( $37.7 \pm 14.44$ days) was shorter than the duration of hospitalization for the ECT-B group ( $56.0 \pm 19.2$ days) (p $=0.04$ ). No serious adverse events were observed during the ECT sessions or during the index hospitalizations.
\end{abstract}

Conclusion: Response rate was high and similar in both of the procedures and the duration of hospitalization was shorter for C-ECT group with no significant increase in serious complicatins and adverse effects.

Key words: ECT, clozapine, schizophrenia

Şizofrenide Klozapin Başlanmasından Önce ya da Sonra EKT - Nöbet Parametreleri, Tedavi Yanıtı ve Hastanede Yatış Süresinin Retrospektif Bir Karşılaştırması

ÖZET

Amaç: Şizofreni tanılı hastalarda klozapin ile eşzamanlı olarak uygulanan elektrokonvulziv tedavinin (EKT) daha iyi tedavi yanıtı ve hastanede yatış süresinde kısalmaya neden olma olasılığını incelemek amaçlanmıştır.

Yöntemler: Kadın psikiyatri kliniğimizde 5 yıl boyunca (01.02.2014 ve 01.02.2019 arasında) yatarak tedavi gören şizofreni tanılı hastaların tıbbi kayıtları retrospektif olarak incelendi. Tedavi yanııııı değerlendirmede Klinik Global İzlem - İyileşme (KGi-I) ölçeği kullanılmıştı.

Bulgular: EKT ile tedavi edilmiş olan 191 olgu içinde; 8 şizofreni olgusu EKT ve eşzamanlı klozapin ile tedavi edilmiş (K-EKT) ve 14 olguya ise önce EKT uygulanmış, sonrasında klozapin tedavisine başlanmışt। (EKT-0̈). İki grup arasında EKT seans sayıları ve nöbet süreleri açııından anlamlı fark yoktu ( $p>0.05$ ). EKT'ye iyi ya da hafif yanıt oranının (KGi-i: 2 ya da 3 ), K-EKT grubunda \%75 ( $n=6)$; EKT-0̈ grubunda ise \%85,7 $(n=12)$ olduğu görüldü. Ortalama KGi-i̇ skorları arasında gruplar arasında anlamlı fark yoktu ( $p>0.05)$. K-EKT grubunun hastanede yatış süresi ( $37,7 \pm 14,44$ gün), EKT-0̈ grubundan (56,0 $\pm 19,2$ gün) daha kısaydı ( $p=0,04)$. EKT seansları sırasında ya da yatışlar süresince ciddi yan etki görülmedi.

Sonuç: Her iki uygulamada da tedaviye iyi yanıt yüksek orandaydı ve uygulamalar arasında anlamlı fark yoktu. EKT ile eşzamanlı klozapin uygulamasının hastanede yatış süresini anlamlı oranda kısaltırken ciddi komplikasyonlar ve yan etkilerde artışına neden olmadığı görüldü.

Anahtar kelimeler: EKT, klozapin, şizofreni 
$\mathbf{T}$ he first electroconvulsive therapy (ECT) device was invented by Ugo Cerletti and Lucio Bini in 1938 and was used in the treatment of a patient with the diagnosis of schizophrenia (1).

Today, there are variations in the rates of ECT use for different psychiatric disorders between countries. In Europe and North America, ECT is generally used for depression and affective disorders (2). There can be changes in the rates of ECT use between years, largely because of changing attitudes of psychiatrists towards ECT (3). Bipolar disorder (32.8\%) and schizophrenia (29.1\%) were the two of the most frequent diagnoses for the patients who were treated with ECT in our hospital as it was reported in a study documenting the 3 years of the practice of ECT (4).

Clozapine is the treatment of choice in refractory schizophrenia (5). ECT is the treatment indicated for refractory conditions, it is markedly effective as an acute treatment of clozapine-refractory schizophrenia, when used as an augmentation strategy (6). Despite the evidence favoring ECT augmentation of pharmacotherapy, particularly clozapine, in treatment resistant schizophrenia $(7,8)$, because of the inadequacy of studies in this field; ECT finds different places in treatment guidelines: American Psychiatric Association (APA) recommends ECT in treatment resistance since 2008, but National Institute for Health and Care Excellence Guidelines (NICE) still limits the recommendation only to the cases where catatonia accompanies $(5,9)$. In addition to the treatment recommendations for schizophrenia that suggest the use of ECT in catatonia (10), there are also views that suggest ECT as an effective option in treatment resistant schizophrenia (11) and there is beneficial additive effect of ECT-clozapine combination (12). According to a Cochrane systematic review; especially when rapid symptom reduction is needed and response to medication is limited; ECT combined with antipsychotics is a suitable option (13) and ECT is expected to be effective in clozapine resistance (14).

Until recently, our knowledge about ECT with concomitant clozapine treatment was based on case reports and case series, but there has been recent studies including a controlled study of 18 patients reporting improvement in positive symptoms, and a prospective randomized controlled study of 39 patients which reports $\% 50$ positive response increased the amount of evidence $(15,16)$.
Aims

The aim of this retrospective study was to investigate the clinical consequences of ECT augmentation of clozapine and discover the differences between ECT with concomitant clozapine (C-ECT) and ECT before the initiation of clozapine (ECT-B).

The main hypothesis was that adjuvant ECT with clozapine would lead to better acute treatment response and fewer days in hospital without significant increase in medical complications.

\section{METHOD}

Study design

The study sample consisted of the inpatients with the diagnosis of schizophrenia who were treated with both ECT and clozapine because of treatment resistance in a period of 5 years (between 01.02.2014 - 01.02.2019) in the women's mental health inpatient clinic of our hospital. The medical records of the patients who received ECT while already using clozapine were compared with the patients who were started clozapine after ECT sessions were over. Patients with serious medical comorbidity and mental retardation were excluded because of the possibility of confounding effect.

\section{Patient selection and data sources}

Our clinic is an inpatient tertiary care center for psychiatric referrals from the region. Indications for inpatient psychiatric care were risk of suicide, risk of homicide and inability to care for oneself. There were 33 beds in the inpatient unit that the retrospective data was derived, the unit was part of the female psychiatry clinics of the research and training hospital for psychiatric disorders. During the survey period (February 2014- February 2019), the total number of psychiatric hospitalizations to the unit was 2738 , and during this period 191 female patients received ECT. Two cases with serious medical comorbidity (gastric carcinoma and chronic renal failure) and two cases with mental retardation were excluded. Regarding the patients with the diagnosis of schizophrenia; there were 8 cases who received ECT concomitant with clozapine (C-ECT) and 14 cases who were treated with ECT before the initiation of clozapine (ECT-B) in our study. The diagnosis were made according to Diagnostic and Statistical Manual of Mental Disorders- Fifth Edition (DSM-5) criteria. Treatment resistance for schizophrenia was defined as resistance to two or more antipsychotics and duration of illness more than two years. The diagnoses and the presence of treatment resistance were confirmed by two different psychiatrists 
of the clinic during the hospitalization (17). ECT augmentation of clozapine was used when there were at least moderate psychotic symptoms that prevented discharge from hospital despite continuous clozapine treatment.

\section{Electroconvulsive therapy (ECT)}

Since 2006, ECT has been administered with anesthesia in our hospital (18).Written informed consent were obtained from the patients themselves, or from their legal representatives as part of ECT regulations in our country. In emergency situations such as refusal of oral intake resulting in malnutrition or severe suicidal risk, when there is no legal representative available, ECT may be performed by the consent of two psychiatrists. ECT with anesthetic and muscle relaxant was applied with a frequency of thrice a week. Propophol $(0,75-1 \mathrm{mg} / \mathrm{kg})$ was used for anesthesia and succinylcholine $(0.5 \mathrm{mg} / \mathrm{kg})$ was used as muscle relaxant. ECT was applied with Thymatron System IV integrated ECT instrument- a brief-pulse-square-wave ECT device (Somatics, LCC, Lake Buff, III). with bilateral electrode placement. Half-age method was used in determining initial stimulus intensity. When the patient was using clozapine, initially the stimulus dose was decreased $10 \%$ because of the possible decrease in seizure threshold. If there was history of recent use of benzodiazepine or antiepileptic agents, the stimulus dose was increased $10 \%$. Shorter than 25 seconds was considered inadequate seizure, longer than 120 seconds was considered as a prolonged seizure. Restimulation was performed with a higher intensity if the seizure lasted less than 20 seconds. When the duration of seizure was as low as $25-30$ seconds, the stimulus dose was increased $10 \%$ in subsequent ECT sessions. Ventilation was applied with face-mask. Oxygenation was continuously monitored with pulse oximetry. Noninvasive positive pressure ventilation with $100 \%$ oxygen was used for assisting respiration. All the patients were also monitored with electrocardiogram (ECG), electromyography (EMG) and electroencephalogram (EEG). The indication for adjuvant ECT with clozapine was unresponsiveness to other treatments.

\section{Instruments}

Socio-demographic data form

There were three kinds of medical records; the electronical hospital records, inpatient clinical forms and ECT Unit data charts. All the relevant clinical information from previously recorded reports and charts were condensed in the data form which was prepared by the researchers.
Clinical Global Impression of Improvement Scale

Treatment response was determined with psychiatric evaluation and recorded with the Clinical Global Impression of Improvement (CGI-I) scale as a part of routine evaluation of all the patients receiving ECT. It is a 7-point scale $(0$ $=$ not assessed, $1=$ very much improved, $2=$ much improved, $3=$ minimally improved, $4=$ no change, $5=$ mini mally worse, $6=$ much worse, $7=$ very much worse). It is considered a robust and quick measure of efficacy if the clinician knows the patient well and is commonly used for measuring the effect of pharmacotherapy (19) and ECT (20). CGI-I scores were determined by the treating clinicians of the patients during the hospitalizations and were recorded in the medical files.

\section{Statistical Analysis}

IBM SPSS Statistics 21.0 (IBM Corp., Released 2012. IBM SPSS Statistics for Windows, Version 21.0, IBM Corp., Armonk, NY, USA) was used in statistical analysis. For the continuous variables, descriptive statistics in mean and standard deviation were calculated. Median values were also presented when considered informative. For categorical variables, frequencies and percentages were presented. Since the data distribution from ECT with Clozapine Treatment (C-ECT) and ECT Before Initiation of Clozapine (ECT-B) groups were not normal, comparisons were made with Mann-Whitney U Test.

\section{Ethics}

The study has been performed in accordance with the ethical standards as laid down in the 1964 Declaration of Helsinki and its later amendments or compatible ethical standards. The study was approved by the ethics committee of the institution (18.01.2019-2446).

\section{RESULTS}

Socio-demographic and clinical findings

There were 8 cases in the C-ECT group and 14 cases in the ECT-B group. Mean age of the C-ECT group was $37.1 \pm$ 9.90, and $40.8 \pm 10.15$ in the ECT-B group. Mean duration of illness was $12.7 \pm 7.28$ years in C-ECT group and $12.6 \pm$ 8.06 years in ECT-B group. Mean number of previous hospitalizations for patients in C-ECT group was $3.8 \pm 2.74$, it was $3.5 \pm 2.53$ in ECT-B group. Clinical features of the patients are presented in Table 1. 
Table 1. Clinical Features and Medications of the Patient Groups

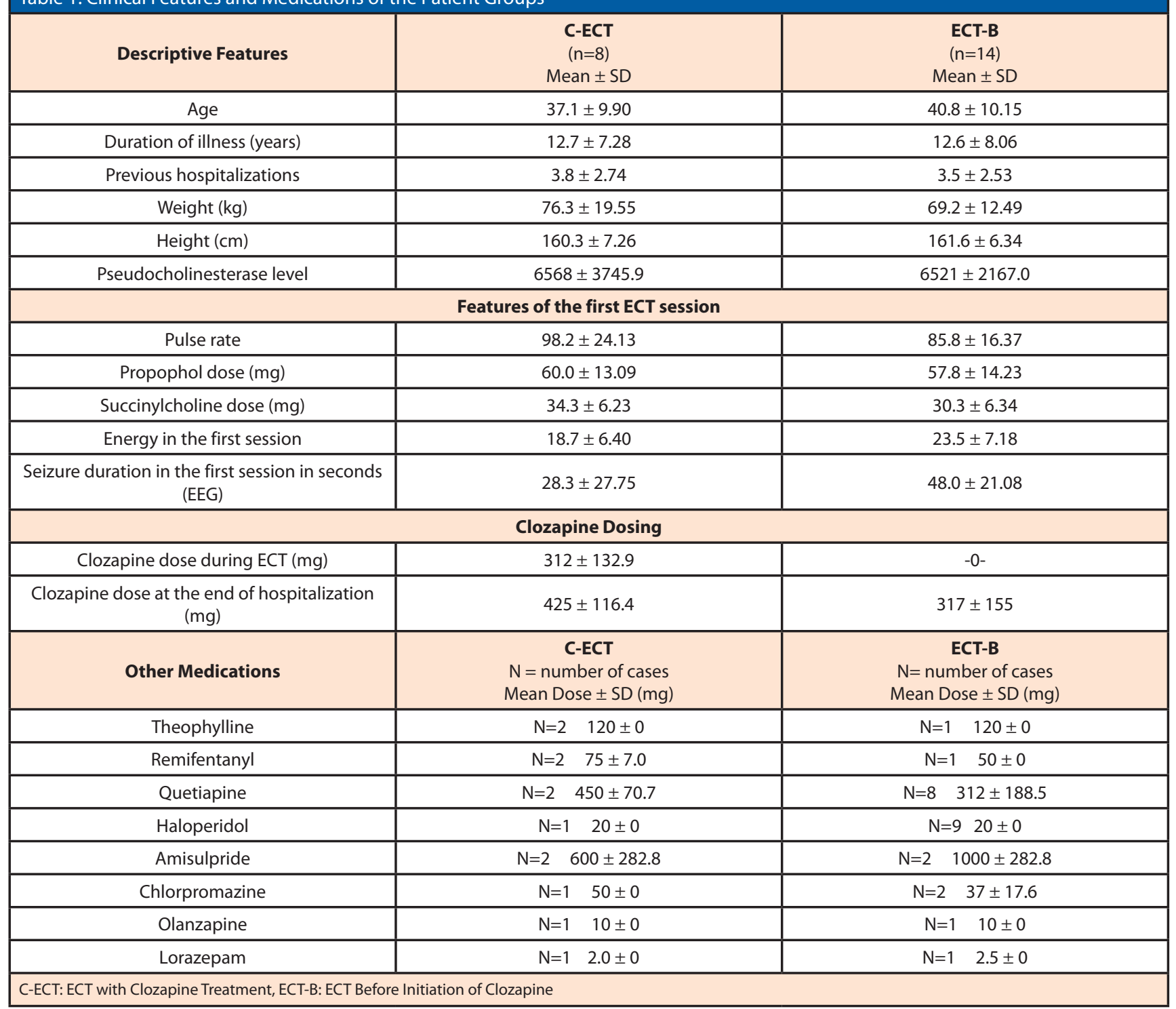

The choice of anesthetic agent was propophol, mean dose was $60.0 \pm 13.09 \mathrm{mg}$ in C-ECT group and $57.8 \pm 14.23 \mathrm{mg}$ in ECT-B group. Succinylcholine was used for all patients as muscle relaxant, mean dose being $34.3 \pm 6.23 \mathrm{mg}$ in C-ECT group, $30.3 \pm 6.34 \mathrm{mg}$ in ECT-B group. Clozapine dose during ECT was $312 \pm 132.9 \mathrm{mg}$ in C-ECT group. Patients in the ECT-B group were not using clozapine during the ECT sessions; for these patients, ECT was administered before the initiation of clozapine treatment. Clozapine doses at the time of discharge from hospital were $425 \pm 116.4$ for C-ECT group and $317 \pm 155$ for ECT-B group. The clozapine doses at discharge were higher for the C-ECT group, but the difference was not significant $(p=0.083)$. Energy, seizure duration and other features of the first ECT session and clozapine doses are also presented in Table 1.

\section{Medication}

When the duration of seizure shortened significantly,in line with the institutional protocols of the ECT center, theophylline was given intravenously with the dose of 120 $\mathrm{mg}$ to two of the patients in C-ECT group and to one of the patients in ECT- B group 15 minutes before the procedure for decreasing the seizure threshold. When it was not appropriate to use theophylline because of tachycardia, remifentanyl with a dose of $1 \mathrm{mg} / \mathrm{kg}$ was added to the pre-ECT medications by the anesthesiologist with the aim of decreasing the dose of propophol to mitigate its effect on seizure threshold (Propophol increases the seizure threshold and addition of remifentanyl enables us to use propophol in half-dose). 2 patients in the C-ECT group 
and one patient in ECT-B group were given remifentanyl. Patients were also given additional psychopharmacological agents during the hospitalization. The use of other medications combined with clozapine were given in Table 1.

\section{Remission and response rates}

Clinical outcome was scored with CGI-I scale. There were 2 patients in the C-ECT group who did not improve and 6 patients (75\%) improved at least minimally. 7 (50.0\%) patients significantly improved $(\mathrm{CGI}-\mathrm{I}=2)$. There were also 2 patients in the ECT-B group who did not improve and 12 patients (85.7\%) improved at least minimally. CGI-I results of the groups are presented in Table 2.

\section{Medical Complications During ECT}

Prolonged confusion was the reason for premature cessation of ECT in two patients in the ECT-B group. The other complications that occurred during the ECT sessions did not prevent completion of the course of ECT. Confusion was observed in 3 patients in the ECT-B group. Inefficient seizures were observed in 5 patients in the C-ECT group and 6 patients in the ECT-B group. No deaths occurred during the ECT sessions or during the index hospitalizations and no severe adverse event such as fractures or cardiac arrest was observed. There were no prolonged seizures and significant increase in complications ( $p>0.05$ ). Medical complications during ECT sessions are presented in Table 2.

\begin{tabular}{|c|c|c|}
\hline $\begin{array}{l}\text { Clinical Global Impression of } \\
\text { Improvement (CGI-I) }\end{array}$ & $\begin{array}{l}\text { C-ECT } \\
(n=8) \\
N(\%)\end{array}$ & $\begin{array}{c}\text { ECT-B } \\
(n=14) \\
N(\%)\end{array}$ \\
\hline Completely improved (CGI-I = 1) & 0 & 0 \\
\hline Significantly improved (CGI-I = 2) & $3(37.5)$ & $7(50.0)$ \\
\hline Minimally improved $(\mathrm{CGI}-\mathrm{I}=3)$ & $3(37.5)$ & $5(35.7)$ \\
\hline No change $(\mathrm{CGI}-\mathrm{I}=4)$ & $2(25.0)$ & $2(14.3)$ \\
\hline $\begin{array}{l}\text { Premature ending due to medical } \\
\text { complications }\end{array}$ & 0 & $2^{*}$ \\
\hline \multicolumn{3}{|c|}{$\begin{array}{c}\text { Medical Complications } \\
\left.\text { (Pearson Chi-Square }=2.112, p=0.348^{\#}\right)\end{array}$} \\
\hline None & 3 & 5 \\
\hline Confusion & 0 & 3 \\
\hline Inefficient seizure & 5 & 6 \\
\hline \multicolumn{3}{|c|}{$\begin{array}{l}\text { C-ECT: ECT with Clozapine Treatment, ECT-B: ECT Before Initiation of Clozapine, } \\
\text { *confusion, \#:4 cells }(66,7 \%) \text { have expected count less than } 5 \text {. The minimum } \\
\text { expected count is } 1,09 .\end{array}$} \\
\hline
\end{tabular}

Comparisons of Distinctive Treatment Outcomes

Mean number of ECT was $8.7 \pm 3.24$ sessions with a median of 8 in C-ECT group and $9.0 \pm 2.63$ sessions with a median of 9 sessions in ECT-B group; similar in the two groups $(p>0.05)$. Mean seizure duration was $42.5 \pm 21.17$ seconds in C-ECT group and $39.7 \pm 13.8$ seconds in ECT-B group in EEG and it was $30.7 \pm 9.41$ seconds in C-ECT group, $29.8 \pm$ 9.96 in the ECT-B group in EMG; they were also similar in duration $(p>0.05)$.

Mean CGI-I scores were $2.8 \pm 0.83$ with a median of 3 in C-ECT group and $2.6 \pm 0.74$ with a median of 2 in ECT-B group. There was no significant difference between CGI-I scores $(p>0.05)$.

Mean duration of hospitalization was $37.7 \pm 14.44$ days (median: 40 days) in the C-ECT group and it was significantly shorter from the mean duration of hospitalization of the ECT-B group which was $56.0 \pm 19.2$ days (median: 51 days) $(Z=-2.048, p=0.042)$. Comparisons of treatment outcomes are presented in Table 3.

\section{DISCUSSION}

Duration of hospitalization was significantly shorter in the C-ECT group in our study. As we know from the previous reports, mean duration of hospitalization for the patients who were not treated with ECT was 22 days and mean duration of hospital stay for the patients who were treated with ECT with different diagnoses was 33 days in our hospital (4). Duration of hospitalization for the ECT-B group was significantly longer when it was compared to the C-ECT group or the previously reported mean durations of hospitalizations. The time needed for titration of clozapine from zero to a therapeutic dose was one of the main reasons for longer duration of hospitalization in the ECT-B group. Such an extra duration of hospitalization in the C-ECT group were not necessary because they were already using clozapine and they continued to use clozapine during the ECT procedure. 


\begin{tabular}{|c|c|c|c|c|}
\hline & $\begin{array}{c}\text { C-ECT } \\
(n=8) \\
\text { Mean } \pm \text { SD }\end{array}$ & $\begin{array}{c}\text { ECT-B } \\
(n=14) \\
\text { Mean } \pm \text { SD }\end{array}$ & $\mathbf{Z}$ & $\mathbf{p}$ \\
\hline Number of ECT sessions & $\begin{array}{c}8.7 \pm 3.24 \\
(\text { median }=8)\end{array}$ & $\begin{array}{c}9.0 \pm 2.63 \\
\text { (median=9) }\end{array}$ & -0.415 & 0.714 \\
\hline $\begin{array}{l}\text { Seizure duration in } \\
\text { seconds (EEG) }\end{array}$ & $\begin{array}{l}42.5 \pm 21.17 \\
\text { (median=34) }\end{array}$ & $\begin{array}{l}39.7 \pm 13.80 \\
(\text { median }=39)\end{array}$ & -0.137 & 0.920 \\
\hline $\begin{array}{l}\text { Seizure duration in } \\
\text { seconds (EMG) }\end{array}$ & $\begin{array}{c}30.7 \pm 9.41 \\
\text { (median }=28)\end{array}$ & $\begin{array}{c}29.8 \pm 9.96 \\
(\text { median }=28)\end{array}$ & -0.239 & 0.815 \\
\hline CGI-I & $\begin{array}{c}2.8 \pm 0.83 \\
(\text { median }=3)\end{array}$ & $\begin{array}{c}2.6 \pm 0.74 \\
\text { (median=2) }\end{array}$ & -0.665 & 0.570 \\
\hline $\begin{array}{c}\text { Duration of hospitalization } \\
\text { in days }\end{array}$ & $\begin{array}{l}37.7 \pm 14.44 \\
\text { (median }=40)\end{array}$ & $\begin{array}{l}56.0 \pm 19.20 \\
(\text { median }=51)\end{array}$ & -2.048 & 0.042 \\
\hline
\end{tabular}

Inpatient treatment is one of the costliest practices in medical expenditures (21). In addition to the economic costs of a long hospital stay, being hospitalized in a closed psychiatric ward, usually is not a pleasant experience as perceived by the patients. Longer days in hospital are also associated with negative consequences such as increased stigmatization (22).

To date, no life-threatening side-effects or deaths has been reported in the literature for the combination of ECT and clozapine. Preliminary data from nonrandomized open-label studies suggest that addition of ECT may be an effective alternative for patients with clozapine-resistant symptoms (15). Although available data indicate that ECT is an effective acute treatment for schizophrenia, including treatment-resistant cases, the number of controlled studies is still small, and clinicians are less inclined to recommend ECT for this population (17). In our study, there was no significant difference between C-ECT and ECT-B groups and the response rates were high in both groups. For psychotic disorders, women have higher ECT response and remission rates as reported previously in the literature (23). A previous naturalistic study from a different center in our country also reported high response rates, which the researchers interpreted to be due to careful selection of possible good responders for ECT by clinicians as they conclude (24).

Clozapine doses during ECT were in the therapeutic range (target dose for female non-smokers $=250 \mathrm{mg} /$ day, female-smokers $=450 \mathrm{mg} /$ day). Clozapine doses at the time of discharge were also higher in C-ECT group, this was probably due to the fact that clozapine initiation time was earlier in these patients. Although duration of illness was similar in both groups, treatment resistance could also be a factor warranting higher doses of clozapine in the C-ECT group.

Seizure durations were not different in the C-ECT and ECT-B groups. Although clozapine decreases seizure threshold, we did not encounter any prolonged seizures. Instead, there were short and ineffective seizures in 5 sessions during ECT with clozapine. Our institutional protocol that recommended decreasing the first stimulus dose $10 \%$ for patients using concomitant clozapine during ECT could possibly be the reason for the seizure durations' being similar across the groups. Succinylcholine and propophol were the principal medications for modified ECT procedure. Propophol which we have used in all ECT sessions is an agent that increases seizure threshold and this could be another reason that we did not observe prolonged seizures.

Addition of theophylline or remifentanyl were needed to ensure effective seizures in 6 patients in the C-ECT group. Inefficient seizures were also observed in patients in the ECT-B group and this was surpassed by increasing the stimulus dose and addition of theophylline or remifentanyl.

Number of ECT sessions were not different across C-ECT and ECT-B groups in our study, with a median of eight and nine sessions respectively. These results were in line with previous studies from our institution reporting mean number of ECT sessions as $7.89 \pm 2.86$ (4). Courses of adjuvant ECT ranging from six to ten sessions were previously reported to be effective in schizophrenia, but the number of sessions varies in different studies (13). When ECT was used with the purpose of clozapine augmentation in treatment resistant schizophrenia, it was also suggested that 
the number of sessions should be more compared to other indications of ECT (18).

The major limitation of our study was that it was not possible to randomize patients to their respective treatment groups because our study was a retrospective chart review. The relatively small sample size and the sample's consisting of only female patients were also limitations. While approaching resistance to clozapine treatment, the serum levels of clozapine were not detected in our study and there could be patients who were resistant to clozapine because they were rapid metabolizers. Detection of serum levels of clozapine was not a routinely available test in our hospital, but we recommend considering clozapine serum levels for future studies and clinical decisions.

Since this was a naturalistic retrospective study, the patients were also given other medications with clozapine. Randomized controlled trials are needed in this topic for overcoming this limitation.

Although the complications in the C-ECT and ECT-B groups were similar in frequency in our study, it is worth mentioning that there can be other complications of ECT and clozapine treatment as we know from the literature: The most serious complication reported in the literature until today is pulmonary emboli during the adjunctive ECT with clozapine, but it has been difficult to claim a cause and effect relationship with the procedure, because there is only one case (25). Supraventricular tachycardia (26), atrial fibrillation (27), Takotsubo cardiomyopathy (28) and aspiration risk under general anesthesia (29) were other serious medical consequences reported in the literature. Prolonged seizures, postictal cognitive dysfunction, tachycardia and fluctuations in blood pressure were other reported side effects of adjunctive ECT with clozapine.

We did not find any significant increase in complications in clozapine-ECT combination, moreover; there is a chance that it decreases the time spent in the inpatient unit. We suggest that when ECT is indicated for a patient using clozapine, instead of cessation of clozapine treatment before ECT, continuing clozapine treatment and augmenting clozapine with concomitant ECT is a favorable option. This may decrease the days spent in hospital without significant increase in medical complications in patients with schizophrenia. Studies with larger sample sizes in both genders would enhance our knowledge in combination of clozapine and ECT.

\section{Conflict of Interests}

This research did not receive any specific grant from funding agencies in the public, commercial, or not-for-profit sectors. The authors report no conflict of interest. The authors alone are responsible for the content and writing of the paper.

\section{REFERENCES}

1. Faedda GL., Becker I, Baroni A, et al. The origins of electroconvulsive therapy: Prof. Bini's first report on ECT. J Affect Disord. 2009;120:12-5. DOI: 10.1016/j.jad.2009.01.023

2. Leiknes KA, Jarosh-von-Schweder L, Hoie B. Contemporary use and practice of electroconvulsive therapy worldwide. Brain Behav. 2012; 2:283-44. DOI:10.1002/brb3.37

3. Horneland M. The changing utilization of electroconvulsive therapya longitudinal study in a Norwegian catchment area, 1970-1986. Nord Psykiatr Tidsskr 1989; 43:249-54. DOI:10.3109/08039488909098662

4. Canbek O, Menges OO, Atagun Ml, et al. Report on 3 years' experience in electroconvulsive therapy in Bakirkoy Research and Training Hospital for psychiatric and neurological diseases: 20082010. J ECT 2013; 29:51-7. DOI:10.1097/YCT.0b013e318282d126

5. NICE, 2014. Psychosis and Schizophrenia in Adults: Treatment and Management (Clinical Guideline 178). Royal College of Psychiatrists, London

6. Braga RJ, John M, Schooler NR, et al. Continuation Electroconvulsive Therapy for Patients With Clozapine-Resistant Schizophrenia: A Pilot Study. J ECT. 2019; 35(3):156-60. DOI: 10.1097/ YCT. 0000000000000588

7. Havaki-Kontaxaki BJ, Ferentinos PP, Kontaxakis VP, et al. Concurrent administration of clozapine and electroconvulsive therapy in clozapine-resistant schizophrenia. Clin Neuropharmacol 2006; 29:52-6. DOI: 10.1097/00002826-200601000-00012

8. Kupchik M, Spivak B, Mester R, et al. Combined electroconvulsiveclozapine therapy. Clin Neuropharmacol 2000; 23:14-6. DOI:10.1097/00002826-200001000-00003

9. Jaffe R. The Practice of Electroconvulsive Therapy: Recommendations for Treatment, Training, and Privileging: A Task Force Report of the American Psychiatric Association. American Journal of Psychiatry 2002; 159:331. DOI:10.1176/appi.ajp.159.2.331

10. Pompili $M$, Lester D, Dominici $G$, et al. Indications for electroconvulsive treatment in schizophrenia: a systematic review. Schizophr Res 2013; 146:1-9. DOI:10.1016/j.schres.2013.02.005

11. Weiner RD, American Psychiatric Association Committ. The Practice of Electroconvulsive Therapy: Recommendations for Treatment Training, and Privileging: a Task Force Report of the American Psychiatric Association, 2nd edn. Washington, DC: American Psychiatric Association; 2001.

12. Buckley P, Miller A, Olsen J, et al. When symptoms persist: clozapine augmentation strategies. Schizophrenia Bulletin, 2001; 27:615-28. DOI:10.1093/oxfordjournals.schbul.a006901

13. Tharyan $P$, Adams $C E$. Electroconvulsive therapy for schizophrenia. Cochrane Database Syst Rev 2005; 2:CD000076. DOI: 10.1002/14651858.CD000076.pub2

14. Arumugham SS, Thirthalli J, Andrade C. Efficacy and safety of combining clozapine with electrical or magnetic brain stimulation in treatment-refractory schizophrenia. Expert Rev Clin Pharmacol 2016; 9:1245-52. DOI: 10.1080/17512433.2016.1200971

15. Petrides G, Malur C, Braga RJ, et al. Electroconvulsive therapy augmentation in clozapine-resistant schizophrenia: a prospective, randomized study. Am J Psychiatry 2015; 172:52-8. DOI: 10.1176/ appi.ajp.2014.13060787 
16. Masoudzadeh A, Khalilian AR. Comparative study of clozapine, electroshock and the combination ECT with clozapine in the treatment resistant schizophrenic patients. Pak J Biol Sci 2007; 10:4287-90. DOI: 10.3923/pjbs.2007.4287.4290

17. Braga RJ, John M, Schooler NR, et al. Continuation electroconvulsive therapy for patients with clozapine-resistant schizophrenia: a pilot study. J ECT 2019; 35:156-61. DOI: 10.1097/YCT.0000000000000588

18. Saatcioglu O, Tomruk NB. Practice of electroconvulsive therapy at the research and training hospital in Turkey. Soc Psychiatry Psychiatr Epidemiol 2008; 43:673-7. DOI:10.1007/s00127-008-0351-z

19. Masand P, O'Gorman C, Mandel FS. Clinical Global Impression of Improvement (CGI-I) as a valid proxy measure for remission in schizophrenia: analyses of ziprasidone clinical study data. Schizophr Res 2011; 126:174-83. DOI:10.1016/j.schres.2010.10.024

20. Özdemir A, Aksoy Poyraz C, Erten E, et al. Electroconvulsive therapy in women: a retrospective study from a mental health hospital in Turkey. Psychiatr Q 2016; 87:769-79. DOI:10.1007/s11126-016-9425-3

21. Pan YJ, Kuo KH, Yeh LL. Healthcare cost, service use and mortality in major psychiatric disorders in Taiwan. J Affect Disord 2019; 246:11220. DOI:10.1016/j.jad.2018.12.046

22. Fresán A, Robles-García R, Madrigal E, et al. Demographic and clinical features related to perceived discrimination in schizophrenia. Psychiatry Res 2018;262:427-30. DOI:10.1016/j.psychres.2017.09.019

23. Holm J, Brus O, Bave U, et al. Improvement of cycloid psychosis following electroconvulsive therapy. Nord J Psychiatry, 2017; 71:40510. DOI:10.1080/08039488.2017.1306579

24. Simsek GG, Zincir S, Gulec H, et al. Do ictal EEG characteristics predict treatment outcomes in schizophrenic patients undergoing electroconvulsive therapy? Nord J Psychiatry 2015; 69:466 -71. DOI:1 0.3109/08039488.2014.1003403

25. Lally J, Tully J, Robertson D, et al. Augmentation of clozapine with electroconvulsive therapy in treatment resistant schizophrenia: $A$ systematic review and meta-analysis. Schizophr Res 2016; 171:21524. DOI:10.1016/j.schres.2016.01.024

26. Beale MD, Pritchett JT, Kellner $\mathrm{CH}$. Supraventricular tachycardia in a patient receiving ECT, clozapine, and caffeine. Convuls Ther 1994; 10:228-31.

27. Urzal F, Oliveira-Maia AJ, Barahona-Correa JB. Acute-Onset Atrial Fibrillation Following an Electrically Induced Generalized Convulsion in a Patient Treated With Clozapine and Electroconvulsive Therapy. J ECT. 2019; 35:15-6. DOI:10.1097/YCT.0000000000000558

28. Grubisha M, Gopalan P, Assam PN. Takotsubo cardiomyopathy in a young man after manintenance electroconvulsive therapy and clozapine initiation: a case report. J ECT 2014; 30:40-1. DOI: 10.1097/ YCT.0000000000000111

29. Estime SR, Berg SM, Henry ME. Clozapine-Associated Aspiration During Electroconvulsive Therapy. J ECT 2019; 35:133-34. DOI: 10.1097/YCT.0000000000000543

30. Grover S, Hazari N, Chakrabarti S, et al. Augmentation of clozapine with ECT: observations from India. Am J Psychiatry 2015; 172: 487. DOI:10.1176/appi.ajp.2014.14091170. 